\title{
E-COMMERCE DI ERA INDUSTRI 4.0 DAN SOCIETY 5.0
}

\author{
Decky Hendarsyah \\ Sekolah Tinggi Ilmu Ekonomi (STIE) Syariah Bengkalis \\ deckydb@gmail.com
}

\begin{abstract}
This paper discusses e-commerce, industry 4.0 and society 5.0 which includes definitions, history, framework and dimensions of technology. From this scope, a comparison was made between industry 4.0 and society 5.0 and a discussion on the alignment and impact of industry 4.0 and society 5.0 on e-commerce. After a deeper comparison and discussion, it can be concluded that technology society 5.0 is a continuation of industry technology 4.0. Then there is technology alignment between e-commerce with the era of industrial 4.0 and society 5.0, where e-commerce technology follows and adapts its technology to each of those eras. The era of industrial 4.0 and society 5.0 had many positive impacts on the development and progress of e-commerce.
\end{abstract}

Keywords: E-commerce, Industry 4.0, Society 5.0, Digital Transformation.

\begin{abstract}
ABSTRAK
Tulisan ini membahas tentang e-commerce, industri 4.0 dan society 5.0 yang mencakup definisi, sejarah, kerangka dan dimensi teknologi. Dari cakupan tersebut dilakukan perbandingan antara industri 4.0 dan society 5.0 serta pembahasan mengenai keselarasan dan dampak antara industri 4.0 dan society 5.0 terhadap e-commerce. Setelah dilakukan perbandingan dan pembahasan lebih mendalam maka dapat ditarik kesimpulan bahwa teknologi society 5.0 merupakan kelanjutan dari teknologi industri 4.0. Kemudian terjadi keselarasan teknologi antara e-commerce dengan era industri 4.0 dan society 5.0, dimana teknologi $e$ commerce mengikuti dan menyesuaikan teknologinya dengan masing-masing era tersebut. Era industri 4.0 dan society 5.0 banyak memberikan dampak positif terhadap perkembangan dan kemajuan e-commerce.
\end{abstract}

Kata kunci: E-commerce, Industri 4.0, Society 5.0, Transformasi Digital.

\section{PENDAHULUAN}

Teknologi informasi bukanlah sesuatu hal yang susah didapatkan saat ini, karena sudah masuk ke semua lini kehidupan masyarakat. Teknologi informasi terus berinovasi dan bertransformasi serta semakin canggih, dengan kecanggihannya bisa memberikan banyak kemudahan bagi kehidupan masyarakat. Kemudahan tersebut juga dirasakan dalam dunia ekonomi terutama dalam perdagangan. Saat ini perdagangan tidak terlepas dari teknologi informasi. Dengan adanya sinergi antara perdagangan dan teknologi informasi maka terciptalah istilah $e$-commerce.

Di Indonesia pertumbuhan e-commerce sangat pesat, terutama 4 tahun terakhir, peningkatannya mencapai 500 persen, ini juga dibuktikan dari hasil riset 
Google dan termasuk dalam laporan e-Conomy SEA 2018 yang menunjukan bahwa transaksi e-commerce Indonesia mencapai US\$ 27 miliar atau setara dengan Rp 391 triliun (Rahayu 2019).

Disisi lain Direktur Pemberdayaan Informatika, Direktorat Jenderal Aplikasi Informatika Kementerian Kominfo (Kemenkominfo), Septriana Tangkary menyatakan bahwa pertumbuhan nilai e-commerce di Indonesia tahun 2018 mencapai 78 persen. Angka pertumbuhan tersebut merupakan yang tertinggi di dunia. Indonesia merupakan negara 10 terbesar pertumbuhan e-commerce dengan pertumbuhan 78 persen dan berada di peringkat pertama. Sementara Meksiko berada di peringkat kedua, dengan nilai pertumbuhan 59 persen (Zuraya 2019).

Sejalan dengan pertumbuhan e-commerce, pada quartal pertama tahun 2018 Indonesia sempat dihebohkan dengan munculnya istilah revolusi industri 4.0 atau industri 4.0. Hampir semua lini masyarakat dan media mainstream bertanya dan membicarakan serta memberitakan tentang industri 4.0. Tidak lama setelah itu tepatnya tanggal 20 Maret 2018 Kementerian Perindustrian mensosialisasikan bahwa kementeriannya telah merancang Making Indonesia 4.0 yaitu merupakan suatu road map yang terintegrasi untuk mengimplementasikan sejumlah strategi dalam memasuki era industri 4.0. Didalam sosialisasi tersebut Menteri Pendustrian Airlangga Hartarto mengatakan bahwa kita sudah memasuki industri 4.0 sejak tahun 2011, itu ditandai dengan meningkatnya konektivitas, interaksi dan batas antara manusia, mesin dan sumber daya lainnya yang semakin konvergen melalui teknologi informasi dan komunikasi (Kementerian Perindustrian 2018).

Tidak ketinggalan juga para praktisi dan akademisi melakukan kajiankajian dan pembicaraan ilmiah mengenai industri 4.0 yang disandingkan dengan bidang keilmuan dan kepakaran mereka masing-masing. Sampai saat tulisan ini dibuat topik tentang industri 4.0 masih tetap hangat diperbincangkan dalam forum-forum resmi dan tidak resmi.

Masih hangatnya pembicaraan tentang industri 4.0, dunia dikejutkan dengan pernyataan dari Perdana Menteri Jepang Shinzo Abe pada acara pertemuan Forum Ekonomi Dunia (World Economic Forum/WEF) di Davos Swiss tanggal 23 Januari 2019. Dimana dalam pernyataannya dia mempunyai visi mengenai Masyarakat 5.0 atau Society 5.0. Dia mengatakan bahwa masyarakat 5.0 akan dihubungkan oleh data untuk meningkatkan pertumbuhan di masa depan (Roby 2019; Haryanti 2019).

Dengan pertumbuhan e-commerce yang begitu pesat kemudian melihat perkembangan industri 4.0 dan gambaran mengenai society 5.0, maka penulis bertujuan untuk membahas keselarasan dan dampak era industri 4.0 dan society 5.0 terhadap e-commerce secara umum.

\section{TELAAH LITERATUR}

\section{E-Commerce}

Menurut Laudon et al. $(2014,10)$ e-commerce adalah penggunaan internet, web dan aplikasi untuk transaksi bisnis secara digital antara perusahaan dan individu. Sedangkan menurut Turban et al. $(2015,7)$ e-commerce adalah penggunaan internet untuk membeli, menjual, mengangkut, atau 
memperdagangkan data, barang atau jasa. Kemudian dalam tulisan Savrul et al. $(2011,251)$ mengatakan (OECD 2001, 6) mendefinisikan $e$-commerce dalam dua lingkup, sebagai definisi yang luas dan sempit. Menurut definisi yang luas, $e$ commerce adalah pembelian atau penjualan barang antara bisnis, rumah tangga, individu, pemerintah dan organisasi publik dan swasta lainnya melalui jaringan komputer. Definisi sempit di sisi lain hampir sama dengan definisi luas kecuali instrumen perdagangan terbatas dengan internet.

Turban et al. (2015, 9) menjelaskan bahwa kerangka utama dari $e$ commerce terdiri dari people (penjual, pembeli, perantara, sistem informasi dan lainnya), public policy (kebijakan dan peraturan publik seperti pajak, regulasi dan lainnya), marketing and advertising (pemasaran dan periklanan seperti promosi, konten web, target pemasaran dan lainnya), support services (layanan pendukung seperti logistik, pembayaran, keamanan sistem dan jaringan dan lainnya), business partnerships (kemitraan bisnis seperti program afiliasi, pertukaran dan lainnya).

Laudon et al. (2014, 28-32) berpendapat bahwa sejarah e-commerce terbagi dalam tiga periode yaitu: Invention, merupakan periode penemuan, dimulai pada tahun 1995 dimana penggunaan web pertama kali sebagai alat untuk mengiklankan produk. Selama periode ini e-commerce hanya memasarkan produk melalui iklan statis yang ditampilkan di web perusahaan. Mesin pencari belum canggih dan bandwidth internet kecil. Periode ini berakhir pada tahun 2000 ketika pasar saham anjlok dan ribuan perusahaan menghilang atau di istilahkan "dot-com crash". Consolidation, merupakan periode konsolidasi, dimulai dari tahun 2001 sampai 2006. Selama periode ini e-commerce berubah tidak hanya menjual produk ritel tetapi juga memberikan layanan yang kompleks, seperti layanan pengiriman dan keuangan. Periode ini internet sudah tersebar luas dengan jaringan broadband. Pemasaran produk sudah merambah melalui web, mesin pencari, email, iklan video, iklan media dan iklan mesin pencari. Kemudian sudah menyediakan fasilitas umpan balik di web perusahaan. Reinvention, merupakan periode penemuan kembali, dimulai tahun 2007 beriringan dengan diperkenalkannya iPhone, hingga saat ini e-commerce ditransformasikan ke jejaring sosial yang bisa diakses secara luas oleh perangkat seluler konsumen seperti smartphone dan komputer tablet. Pemasaran ditransformasikan melalui jejaring sosial kemudian menjadi pembicaraan mulut ke mulut dan viral. Perusahaan sudah menggunakan repositori data yang jauh lebih kuat dan menggunakan alat analisis pemasaran sehingga pemasaran terkoordinasi berdasarkan jejaring sosial, mesin pencari, web, platform ponsel dan email.

Pada periode reinvention banyak fitur unik dari teknologi e-commerce dan internet yang datang secara bersamaan dalam satu set aplikasi dengan teknologi media sosial yang disebut sebagai web 2.0 (Laudon et al. 2014, 16). Menurut Turban et al. $(2015,20)$ web 2.0 menggunakan lusinan alat seperti wiki, rss atau $\mathrm{xml}$, blog, mikroblog dan lain-lain. Selain itu Turban secara tersirat berpendapat web 2.0 merupakan representasi e-commerce 2.0, kemudian dia juga mengatakan bahwa e-commerce termasuk e-commerce 2.0 difasilitasi oleh perkembangan ekonomi, sosial dan perusahaan secara digital.

Menurut Turban et al. (2015, 10-11) bahwa tipe utama dari transaksi $e$ commerce terdiri dari Business-to-Business (B2B), Business-to-Consumer (B2C), Business-to-Business-to-Consumer (B2B2C), Consumer-to-Business (C2B), Intrabusiness EC, Business-to-Employees (B2E), Consumer-to-Consumer $(C 2 C)$, 
Collaborative Commerce dan E-Government. Sedangkan Laudon et al. $(2014,19)$ menambahkan tiga tipe utama e-commerce yaitu Social e-commerce, Mobile ecommerce dan Local e-commerce.

Turban et al. (2015) menyebutkan bahwa teknologi dalam e-commerce terdiri dari augmented reality, crowdsourcing, micro payments devices, big data in e-commerce and its analysis, e-payments including bitcoin, develop your own applications, IBM's Pure Data Systems for analytics, Internet of Things (IoT), machine-to-machine (M2M) communications, new devices for e-learning, $3 D$ printing, wearable devices.

Menurut Laudon et al. $(2014,12)$ bahwa didalam teknologi e-commerce terdapat delapan dimensi atau fitur unik yang perlu diperhatikan yaitu: Ubiquity, bisa diartikan dimana-mana, artinya bahwa teknologi internet/web tersedia kapan dan di mana saja seperti: di tempat kerja, di rumah dan di tempat lain melalui perangkat mobile. Berdasarkan marketspace maka jangkauan diperluas melampaui batasan pasar tradisional dan dapat berpindah dari suatu lokasi ke lokasi lain secara geografis. Kemudian transaksi jual beli bisa terjadi di mana saja sehingga kenyamanan pelanggan dapat ditingkatkan dan biaya transaksi berkurang. Global reach, bisa diartikan bahwa teknologi ini menjangkau lintas batas negara yang ada di bumi. Sehingga perdagangan dapat dilakukan secara lintas batas budaya dan negara. Dari segi marketspace dapat berpotensi meraih miliaran konsumen dan jutaan bisnis di seluruh dunia. Universal standards, dapat diartikan bahwa ada satu set standar teknologi, yaitu internet sebagai pondasi teknologi dalam bisnis. Richness, dapat diartikan bahwa teknologi ini kaya akan konten seperti video, audio dan teks. Konten tersebut bisa dimanfaatkan sebagai alat pemasaran. Interactivity, bisa diartikan bahwa teknologi ini bekerja melalui interaksi dengan pengguna. Information density, bisa diartikan bahwa teknologi ini mengurangi biaya informasi dan meningkatkan kualitas informasi itu sendiri. Pemrosesan dan penyimpanan informasi serta biaya komunikasi menjadi turun secara dramatis, sementara itu mata uang, akurasi dan ketepatan waktu meningkat secara pesat. Sehingga informasi menjadi berlimpah, murah dan akurat. Personalization/customization, dapat diartikan bahwa teknologi ini memungkinkan informasi yang disampaikan kepada pelanggan bisa disesuaikan dengan kebutuhan atau karakteristik pelanggan itu sendiri baik pribadi maupun kelompok. Social technology, bisa diartikan bahwa teknologi ini memungkinkan pengguna dapat membuat dan berbagi konten dengan komunitas di seluruh dunia melalui jejaring sosial.

\section{Industri 4.0}

Industri 4.0 merupakan kata lain dari revolusi industri 4.0. Mengenai sejarah revolusi industri Rojko $(2017,79)$ dan Xu (2018, 2943) mengatakan bahwa revolusi industri pertama (industri 1.0) dimulai dengan mekanisasi dan pembangkit tenaga mekanik pada tahun 1800-an. Ini membawa transisi dari pekerjaan manual ke proses manufaktur menggunakan mesin uap (zaman mesin uap); sebagian besar di industri tekstil. Industri 2.0 dimulai tahun 1900-an disebut sebagai zaman listrik dan industrial. Industri 3.0 dimulai tahun 1960-an disebut era informasi, digitalisasi dan otomatisasi elektronik. Industri 4.0 disebut zaman cyber physical systems atau otomatisasi cerdas. 
Bahrin et al. $(2016,137)$ berpendapat bahwa sektor industri penting bagi perekonomian setiap negara dan tetap menjadi pendorong pertumbuhan dan lapangan kerja. Industri, yang dalam konteks ini berfokus pada manufaktur, memberikan nilai tambah melalui transformasi bahan menjadi produk. Istilah industri 4.0 mulai dikenal publik pada tahun 2011, ketika sebuah inisiatif yang disebut industri 4.0 di mana asosiasi perwakilan dari bisnis, politik dan akademisi mempromosikan gagasan itu sebagai pendekatan untuk memperkuat daya saing industri manufaktur Jerman. Jerman memiliki salah satu industri manufaktur paling kompetitif di dunia dan merupakan pemimpin global di sektor peralatan manufaktur. Sejak pemerintah federal Jerman mengumumkan industri 4.0 sebagai salah satu inisiatif utama dari strategi teknologi tinggi pada tahun 2011, topik industri 4.0 telah menjadi terkenal di antara banyak perusahaan, pusat penelitian, dan universitas.

Selanjutnya Rojko (2017, 80) juga mengatakan bahwa konsep dasar industri 4.0 pertama kali dipresentasikan di pameran Hannover pada tahun 2011. Sejak diperkenalkan industry 4.0 di Jerman, industry 4.0 menjadi topik diskusi umum dalam komunitas peneliti, akademik dan industri di berbagai kesempatan. Kemudian $\mathrm{Xu}(2018$, 2941) juga sependapat bahwa industri 4.0 awalnya diperkenalkan selama pameran di Hannover pada tahun 2011; selanjutnya, secara resmi diumumkan pada 2013 sebagai inisiatif strategis Jerman untuk mengambil peran perintis dalam industri yang saat ini merevolusi sektor manufaktur.

Industri 4.0 adalah area baru di mana internet hal-hal bersama dengan cyber physical systems saling berhubungan dengan cara kombinasi perangkat lunak, sensor, prosesor dan teknologi komunikasi memainkan peran besar untuk membuat sesuatu yang memiliki potensi untuk memasukkan informasi ke dalamnya dan akhirnya menambah nilai pada proses manufaktur (Bahrin 2016). Ini juga selaras dengan pendapat Rojko (2017) yang mengatakan bahwa industri 4.0 memiliki gagasan utama yakni memanfaatkan potensi teknologi dan konsep baru seperti: internet, integrasi proses teknis dan proses bisnis di perusahaan, pemetaan digital dan virtualisasi dunia nyata, pabrik cerdas termasuk didalamnya sarana produksi pintar dan produk pintar.

Menurut Bahrin (2016) teknologi yang terkait dengan industri 4.0 adalah sebagai berikut: The Internet of Things (IoT), berfungsi untuk menghubungkan semua perangkat komputasi menggunakan teknologi tertentu. Memungkinkan perangkat berkomunikasi dan berinteraksi satu sama lain dengan pengontrolan yang terpusat. Ini juga bermanfaat dalam menganalisa dan mengambil keputusan secara langsung. Cybersecurity, komunikasi yang andal, identitas canggih dan manajemen akses mesin dan pengguna adalah penting bagi industri 4.0 untuk mengatasi masalah ancaman keamanan siber yang meningkat secara signifikan dengan meningkatnya konektivitas dan penggunaan standar protokol komunikasi. The cloud, meningkatnya kinerja teknologi, data dan fungsionalitas maka disebarkan ke cloud/awan, supaya lebih banyak layanan berbasis data untuk sistem produksi. Lebih banyak usaha yang terkait dengan produksi di industri 4.0 akan membutuhkan peningkatan berbagi data di seluruh lokasi perusahaan. Big data analytics, memungkinkan pengumpulan dan evaluasi data yang komprehensif dari berbagai sumber dan pelanggan untuk mendukung pengambilan keputusan langsung, mengoptimalkan kualitas produksi, menghemat energi dan meningkatkan layanan peralatan. Horizontal and vertical system 
integration, integrasi sistem horisontal dan vertikal di antara perusahaan, departemen, fungsi dan kemampuan akan menjadi lebih kohesif, seiring lintasperusahaan, jaringan integrasi data universal berkembang dan memungkinkan rantai nilai yang benar-benar otomatis. Augmented reality, dapat mendukung berbagai layanan, seperti memilih suku cadang di gudang dan mengirim instruksi perbaikan melalui perangkat seluler. Additive manufacturing ( $3 D$ printing), dapat menghasilkan sejumlah produk yang disesuaikan seperti desain yang kompleks dan ringan, berperforma tinggi dan mengurangi jarak pengangkutan dan persediaan. Simulation, memanfaatkan data realtime untuk mencerminkan kenyataan dalam model virtual, yang mencakup seperti mesin, produk dan manusia. Hal ini memungkinkan operator untuk menguji dan mengoptimalkan pengaturan alat untuk produksi berikutnya, sehingga dapat mengurangi waktu pengaturan alat dan meningkatkan kualitas produk. Robots, lebih mandiri, fleksibel dan kooperatif, mereka akan berinteraksi satu sama lain dan dapat bekerja dengan aman bersama manusia, kemudian belajar dari mereka. Robot lebih murah biayanya dan memiliki jangkauan kemampuan yang lebih besar.

\section{Society 5.0}

Pemerintah Jepang mendefinisikan society 5.0 yaitu masyarakat yang terpusat pada manusia dimana dapat menyeimbangkan antara kemajuan ekonomi dengan penyelesaian masalah sosial menggunakan sistem yang mengintegrasikan dunia maya dan fisik (COJG 2019). Menurut Fukuyama $(2018,47)$ bahwa society 5.0 diajukan oleh pemerintah Jepang merupakan konsep yang jelas. Itu disusun dalam Rencana Dasar Sains dan Teknologi kelima oleh Dewan Sains, Teknologi dan Inovasi, dan disetujui oleh keputusan Kabinet pada Januari 2016.

Kemudian Fukuyama (2018, 47) menjelaskan mengenai tahapan masyarakat (society) berdasarkan sejarah manusia. Society 1.0 didefinisikan sebagai kelompok orang yang berkumpul dan berburu dalam hidup, kemudian berdampingan secara harmonis dengan alam, dimulai dari terciptanya manusia. Society 2.0 membentuk kelompok berdasarkan budidaya pertanian, peningkatan organisasi dan pembangunan bangsa, dimulai dari 13.000 sebelum masehi. Society 3.0 adalah masyarakat yang mempromosikan industrialisasi melalui revolusi industri 1.0, dimulai dari akhir abad 18. Society 4.0 adalah masyarakat informasi yang menyadari peningkatan nilai tambah dengan menghubungkan aset tidak berwujud sebagai jaringan informasi, dimulai dari pertengahan abad 20. Dalam tahapan ini, society 5.0 adalah masyarakat informasi yang dibangun di atas society 4.0, yang bertujuan untuk masyarakat yang lebih makmur.

Fukuyama $(2018,48)$ juga berpendapat bahwa dalam transformasi digital beberapa wiliyah atau negara menggunakan istilah yang berbeda. Eropa menggunakan istilah industri 4.0, Amerika Utara menggunakan istilah industrial internet, Asia menggunakan istilah smart cities, China menggunakan istilah made in China 2025 dan Jepang menggunakan istilah society 5.0. Dimana transformasi digital menggunakan IoT, artificial intelligence, robotics, big data dan blockchain. Hal yang sama juga dikemukakan oleh Nakanishi and Kitano (2018, 4-5).

Dalam society 5.0, nilai baru yang diciptakan melalui inovasi akan menghilangkan kesenjangan regional, usia, jenis kelamin dan bahasa dan memungkinkan penyediaan produk dan layanan yang disesuaikan dengan baik 
untuk beragam kebutuhan individu dan kelompok. Dengan cara ini, memungkinkan untuk mencapai masyarakat yang dapat meningkatkan pembangunan ekonomi dan menemukan solusi masalah sosial. Namun, pencapaian tersebut akan terdapat kesulitan atau kendala, Jepang siap untuk menghadapi secara langsung dengan tujuan menjadi yang pertama di dunia sebagai negara yang menghadapi masalah untuk menghadirkan model masyarakat masa depan (COJG 2019).

Dalam cetak biru society 5.0 untuk tujuan pembangunan berkelanjutan yang dirancang oleh Nakanishi and Kitano (2018, 14) menurut Fukuyama (2018, 50) terdapat teknologi berupa big data, IoT, artificial inteligent, robot, drone, sensor, 3D print, public key infrastructure (PKI), sharing, on demand, mobile, edge, cloud, 5G, virtual reality $(V R)$, augmented reality $(A R)$ dan mixed reality (MR).

Fukuyama $(2018,50)$ mengatakan bahwa tujuan dari society 5.0 adalah untuk mewujudkan masyarakat di mana manusianya menikmati hidup sepenuhnya. Pertumbuhan ekonomi dan perkembangan teknologi ada untuk tujuan itu dan bukan untuk kemakmuran segelintir orang. Meskipun society 5.0 berasal dari Jepang, tujuannya bukan hanya untuk kesejahteraan satu negara. Kerangka kerja dan teknologi yang dikembangkan akan berkontribusi untuk menyelesaikan tantangan masyarakat di seluruh dunia.

\section{PEMBAHASAN}

\section{Perbandingan Industri 4.0 Dan Society 5.0}

Dilihat dari sejarah revolusi industri dan tahapan masyarakat di dunia ini dapat dijelaskan bahwa revolusi industri lahir melalui tahapan-tahapan masyarakat yang saling berkesinambungan. Sedangkan industri 4.0 dan society 5.0 muncul beriringan dimana industri 4.0 lebih dahulu muncul kepermukaan dan lebih fokus kepada industri terutama bidang manufaktur seperti tekstil, otomotif, makanan dan minuman, elektronik, biokimia dan sebagainya. Sedangkan society 5.0 muncul setelah industri 4.0, dimana society 5.0 masih berupa visi dan fokus kepada manusianya. Untuk lebih jelasnya perbandingan waktu dimulainya tahapan masyarakat dan revolusi industri bisa dilihat pada tabel 1. Perbandingan selanjutnya dapat dilakukan dari segi pemanfaatan teknologi dilihat pada tabel 2.

Tabel 1 Perbandingan Waktu Tahapan Masyarakat Dan Revolusi Industri

\begin{tabular}{ccc}
\hline Waktu & Tahapan Masyarakat & Revolusi Industri \\
\hline Awal Manusia Ada & Society 1.0 & - \\
13.000 Sebelum & Berburu & \\
Masehi & Society 2.0 & - \\
Bercocok tanam & Industri 1.0 \\
Society 3.0 & Tahun 1800-an \\
Abad 19 & Society 3.0 & Industri 2.0 \\
& Industri & Tahun 1900-an \\
Abad 20 & Society 4.0 & Industri 3.0 \\
& Informatif dan Kreatif & Tahun 1960-an
\end{tabular}




\begin{tabular}{ccc} 
& Society 5.0 & Industri 4.0 \\
Abad 21 & Super Cerdas & Tahun 2011 \\
& (Visi) & \\
\hline Sumber: Olahan penulis &
\end{tabular}

Tabel 2 Perbandingan Tekonologi Industri 4.0 dan Society 5.0

\begin{tabular}{lcc}
\hline \multicolumn{1}{c}{ Teknologi } & Industri 4.0 & Society 5.0 \\
\hline Big Data & $\checkmark$ & $\checkmark$ \\
Internet of Thing & $\checkmark$ & $\checkmark$ \\
Artificial Inteligent & $\checkmark$ & $\checkmark$ \\
Robot & $\checkmark$ & $\checkmark$ \\
Drone & $\checkmark$ & $\checkmark$ \\
Sensor & $\checkmark$ & $\checkmark$ \\
3D Print & $\checkmark$ & $\checkmark$ \\
Public Key Infrastructure (PKI) & $\checkmark$ & $\checkmark$ \\
Cyber Security & & \\
Sharing & $\checkmark$ & $\checkmark$ \\
On Demand & $\checkmark$ & $\checkmark$ \\
Mobile & $\checkmark$ & $\checkmark$ \\
Edge & $\checkmark$ & $\checkmark$ \\
Cloud & $\checkmark$ & $\checkmark$ \\
5G & $\times$ & $\checkmark$ \\
Virtual Reality (VR) & $\checkmark$ & $\checkmark$ \\
Augmented Reality (AR) & $\checkmark$ & $\checkmark$ \\
Mixed Reality (MR) & $\checkmark$ & $\checkmark$ \\
Sumber: olahan penulis & & \\
Keterangan: & & \\
$\checkmark=$ Ada & &
\end{tabular}

Dari tabel 2 bisa dijelaskan bahwa perbandingan teknologi dari industri 4.0 dan society 5.0 tidak jauh berbeda, karena pada prinsipnya society 5.0 melanjutkan teknologi yang ada pada industri 4.0 dan masih berjalan sampai saat ini. Big data, cloud dan IoT menjadi kebutuhan dan harus diterapkan dalam industri 4.0 dan society 5.0. Robot pada industri 4.0 sudah menggunakan artificial inteligent dan sensor. Teknologi drone digunakan pada industri 4.0 dan society 5.0. $3 D$ Print juga dipakai pada industri 4.0 dan society 5.0. Sedangkan public key infrastructure merupakan salah satu sarana sistem keamanan data yang digunakan dalam society 5.0 dimana Public key infrastructure merupakan bagian dari cyber security dalam industri 4.0.

Sharing merupakan teknologi berbagi informasi yang diterapkan dalam industri 4.0 (Auliani 2019a) dan society 5.0. On demand merupakan teknologi untuk melayani permintaan, ini juga digunakan pada industri 4.0 dan society 5.0. Simulations pada industri 4.0 menggunakan virtual reality, augmented reality dan mixed reality dan teknologi tersebut juga digunakan pada society 5.0. Kemudian teknologi mobile merupakan perangkat seluler yang terintegrasi dengan jaringan seluler edge ( $2 G, 3 G, 4 G$ dan lainnya) dan diterapkan pada industri 4.0 dan society 4.0. 
Sedangkan untuk teknologi $5 G$ pada industri 4.0 belum diterapkan saat ini karena teknologi tersebut walaupun sudah ditemukan dan dipakai, tapi belum diimplementasikan secara masal di dunia (Pertiwi 2018; Rahman 2019). Society 5.0 masih berupa visi, oleh sebab itu bisa merencanakan pemanfaatan teknologi $5 G$ dimasa yang akan datang. Tetapi tidak menutup kemungkinan bahwa industri 4.0 juga akan menggunakan teknologi tersebut dimasa yang akan datang.

\section{E-Commerce Di Era Industri 4.0}

Industri pada umumnya mempunyai prosedur standar dalam operasionalnya, mulai dari penyediaan bahan mentah sampai menghasilkan suatu produk hingga sampai ke konsumen. Pada era industri 4.0 semua prosedur tersebut sudah menggunakan otomatisasi cerdas. E-commerce lahir sebelum industri 4.0, dimana e-commerce sendiri merupakan transaksi bisnis yang dilakukan secara elektronik menggunakan internet. Transaksi bisnis merupakan bagian kegiatan yang dilakukan di dunia industri. Jadi bisa dikatakan secara umum bahwa e-commerce berhubungan dan berkesinambungan dengan industri 4.0. Untuk itu perlu dibahas bentuk hubungan dan keselarasannya dalam hal kerangka, dimensi dan teknologinya.

Industri 4.0 fokus pada industri manufaktur terotomatisasi cerdas dan berkembang dibanyak sektor, sehingga ini akan menciptakan produk yang banyak dan berkualitas di berbagai sektor. Hal tersebut akan berpengaruh terhadap peningkatan transaksi bisnis terutama pada e-commerce. Dimana marketplace akan semakin komplek dan canggih sehingga perusahaan-perusahaan akan tumbuh dan roda perekonomian semakin berputar.

Dalam kerangka e-commerce terdapat orang (people) berupa penjual, pembeli, perantara dan lainnya, pada era industri 4.0 dalam operasionalnya juga membutuhkan orang, sehingga untuk kerangka ini volumenya akan bertambah pada e-commerce. Kerangka e-commerce berikutnya yaitu kebijakan dan peraturan seperti pajak dan regulasi, di era industri 4.0 hal tersebut juga berlaku seperti regulasi operasional industri dan pajak industri, sehingga akan terjadi penyelarasan kebijakan dan peraturan pada e-commerce. Selanjutnya pemasaran dan periklanan merupakan kerangka e-commerce berupa promosi, konten web dan target pemasaran, dalam industri 4.0 juga terdapat kegiatan tersebut seperti produk yang diciptakan harus ditentukan target pemasarannya, sehingga pemasaran dan periklanan pada e-commerce semakin gencar dan lebih kreatif. Kerangka $e$ commerce selanjutnya adalah layanan pendukung seperti logistik, pembayaran dan keamanan sistem dan jaringan, pada industri 4.0 pengaturan logistik sudah menggunakan IoT dan $A I$, sedangkan pembayaran sudah menggunakan online banking dan uang elektronik, dalam hal keamanan sistem dan jaringan sudah menggunakan cyber security, jadi hal tersebut dalam e-commerce akan menyesuaikan. Kerangka $e$-commerce yang terakhir yaitu kemitraan bisnis, hal ini juga sudah ada pada industri 4.0 seperti dalam pengadaan bahan mentah dan distribusi produk jadi, sehingga pada e-commerce tinggal ditingkatkan kemitraannya.

Dalam dimensi teknologi e-commerce terdapat ubiquity dan global reach bisa diartikan dimana-mana dan menjangkau lintas batas negara, maknanya bahwa e-commerce bisa diakses dimana-mana dengan menggunakan internet, pada industri 4.0 hal tersebut menjadi sangat penting seperti pengontrolan produksi bisa 
dikontrol melalui smartphone dan diakses dimana saja, sehingga ubiquity dan global reach pada e-commerce menyesuaikan teknologinya. Kemudian universal standards dapat diartikan bahwa ada satu set standar teknologi yaitu internet, industri 4.0 juga menggunakan internet. Selanjutnya richness dapat diartikan bahwa teknologi ini kaya akan konten seperti video, audio dan teks, industri 4.0 dalam memasarkan produk menggunakan konten yang sama dengan e-commerce. Berikutnya interactivity bisa diartikan bahwa teknologi ini bekerja melalui interaksi dengan pengguna, industri 4.0 sudah mengimplementasikan hal ini dalam horizontal and vertical system integration, simulation dan robots, ecommerce tinggal mengakuisisi teknologi tersebut kedalam interactivity. Kemudian information density diartikan bahwa teknologi ini mengurangi biaya informasi dan meningkatkan kualitas informasi itu sendiri, di industri 4.0 terkait dengan informasi menggunakan teknologi big data dan cloud dimana pemrosesan, penyimpanan informasi dan biaya komunikasi menjadi turun sehingga informasi menjadi berlimpah, murah dan akurat, oleh sebab itu e-commerce bisa menyesuaikan teknologinya. Berikutnya personalization/ customization dapat diartikan bahwa memungkinkan informasi yang disampaikan kepada pelanggan bisa disesuaikan dengan kebutuhan mereka, dalam industri 4.0 ketika menciptakan produk hal ini juga dilakukan, sehingga bisa sinkron dengan $e$ commerce. Dan yang terakhir social technology bisa diartikan bahwa memungkinkan pengguna dapat membuat dan berbagi konten dengan komunitas di seluruh dunia melalui jejaring sosial, ini juga merupakan salah satu strategi teknologi yang diterapkan pada industri 4.0, sehingga akan memudahkan perkembangan e-commerce.

Setelah dibahas mengenai industri 4.0 maka dapat dibuktikan bahwa $e$ commerce dan industri 4.0 memiliki hubungan yang selaras dan berbanding lurus, karena dari segi teknologi, e-commerce akan menyesuaikan teknologinya dengan teknologi yang ada pada era industri 4.0. Kemudian industri 4.0 juga memanfaatkan e-commerce dalam operasionalnya, sehingga $e$-commerce di era industri 4.0 akan lebih berkembang dan maju lagi.

\section{E-Commerce Di Era Society 5.0}

Society 5.0 merupakan visi pemerintahan Jepang dalam meningkatkan kesejahteraan masyarakatnya di masa yang akan datang. Kesejahteraan tersebut diraih dengan memanfaatkan teknologi sehingga bisa menyeimbangkan antara kemajuan ekonomi dengan penyelesaian masalah sosial yang berpusat pada manusia dan mempermudah semua lini kehidupan masyarakat. E-commerce sendiri sudah ada sebelum society 5.0 yang bertujuan juga untuk memudahkan masyarakat dalam bertransaksi bisnis. Jadi bisa dikatakan bahwa e-commerce dan society 5.0 memiliki tujuan dan hubungan yang sama. Tapi hal tersebut harus dibahas berdasarkan kerangka, dimensi dan teknologinya.

Dalam society 5.0 digambarkan bahwa setiap kegiatan yang dilakukan manusia sangat bergantung kepada teknologi. Teknologi sudah menjadi kebutuhan dasar dalam sendi-sendi kehidupan manusia, semua terintegrasi dengan smartphone. Dalam transaksi bisnis masyarakat juga sudah tergantung dengan teknologi sehingga tidak mau lagi melakukan transaksi bisnis secara tradisional. Dengan hal demikian maka e-commerce akan menjadi primadona dalam transaksi bisnis, sehingga prospeknya semakin cerah. Ini juga merupakan salah satu 
pendongkrak munculnya perusahaan-perusahaan start-up baru untuk memenuhi kebutuhan masyarakat secara luas.

Dalam kerangka e-commerce terdapat orang (people) yang merupakan bagian dari masyarakat dalam society 5.0. Kebijakan dan peraturan dalam $e$ commerce ini akan disesuaikan pada era society 5.0 sesuai dengan pemanfaatan dan kemajuan teknologi. Kemudian pemasaran dan periklanan pada e-commerce di era society 5.0 akan semakin mudah karena masyarakat sudah terhubung ke internet dan menjadi gaya hidup mereka. Selanjutnya adalah layanan pendukung seperti logistik, pembayaran dan keamanan sistem dan jaringan, di era society 5.0 tentunya layanan pendukung akan diperkuat dengan memanfaatkan teknologi IoT, $A I$, cloud, robot, drone dan sensor sehingga mempermudah layanan pendukung $e$ commerce termasuk dari segi keamanannya. Dari segi kemitraan bisnis $e$ commerce, pada era society 5.0 akan dipermudah untuk menjalin hubungan kemitraan dengan menggunakan teknologi IoT dan mixed reality.

Dimensi dari teknologi e-commerce terdapat ubiquity, global reach dan universal standards, di era society 5.0 ini sudah menjadi hal yang biasa karena internet sudah menjadi gaya hidup masyarakat yang dapat menjangkau akses lintas batas negara, e-commerce sangat didukung dari dimensi ini sehingga memudahkan masyarakat. Kemudian richness, di era society 5.0 kekayaan konten akan semakin maju karena masyarakat sudah semakin kreatif dan inovatif dalam membuat konten, sehingga e-commerce semakin kaya pertumbuhan kontennya. Selanjutnya interactivity, pada era society 5.0 masyarakat akan dipermudah dalam berinteraksi menggunakan teknologi virtual reality, augmented reality dan mixed reality, sehingga ini akan berdampak baik untuk perkembangan e-commerce. Kemudian information density dan personalization/customization, di era society 5.0 kualitas informasi akan semakin baik karena menggunakan teknologi big data, cloud dan $A I$, sehingga sangat bermanfaat bagi kemajuan dan keberlangsungan $e$ commerce. Terakhir social technology, dalam society 5.0 interaksi antar masyarakat melalui teknologi semakin tinggi, hal ini akan mempercepat pertumbuhan $e$-commerce.

Dari pembahasan kerangka, dimensi dan teknologi antara $e$-commerce dan society 5.0 dapat dibuktikan bahwa e-commerce memiliki tujuan dan hubungan yang selaras dengan society 5.0, yaitu mempunyai tujuan untuk mempermudah kehidupan masyarakat dan dari segi teknologi e-commerce menyesuaikan perkembangan teknologinya dengan society 5.0.

\section{Dampak Industri 4.0 Dan Society 5.0 Terhadap E-Commerce}

Produk yang ditransaksikan dalam e-commerce akan semakin beragam. Era industri 4.0 akan banyak melahirkan produk-produk baru diberbagai bidang, kemudian pada era society 5.0 kehidupan masyarakat sudah berbasis pada teknologi digital dan transaksi online, sehingga e-commerce otomatis akan mentransaksikan produk yang beragam dalam memenuhi kebutuhan masyarakat secara online.

Pertumbuhan perusahaan start-up akan meningkat secara signifikan. Karena era industri 4.0 dan society 5.0 akan melahirkan produk yang beragam dan transaksi bisnis yang semakin tinggi, kemudian kebutuhan akan produk juga semakin tinggi, otomatis akan bermunculan perusahaan-perusahaan untuk 
memenuhi itu semua terutama perusahaan start-up. Dengan berdirinya perusahaan-perusahaan tersebut maka akan membuka lapangan pekerjaan.

Persaingan bisnis akan menjadi lebih ketat. Karena semakin banyak perusahaan yang muncul maka persaingan akan menjadi lebih ketat terutama perusahaan-perusahaan yang memiliki proses bisnis, marketplace dan target pemasaran yang sama.

Produsen, konsumen dan distributor akan bertambah. Ketika produk semakin beragam dan kebutuhan akan produk meningkat otomatis jumlah produsen, konsumen dan distributor semakin bertambah.

Kebijakan dan regulasi publik akan semakin baik. Pemerintah selaku pembuat kebijakan dan regulasi akan selalu membuat, meninjau dan memperbaiki kebijakan dan regulasi supaya kebijakan dan regulasi yang dikeluarkan semakin baik dan menguntungkan semua pihak.

Pemasaran dan periklanan akan tumbuh dan lebih kreatif. Karena era industri 4.0 dan society 5.0 merupakan era transformasi digital yang akan mempermudah pemasaran dan periklanan produk sehingga tumbuh dan lebih kreatif serta akan menarik minat konsumen.

Layanan pendukung e-commerce akan semakin baik dan lebih komplek. Penggunaan teknologi IoT, big data, cloud, AI dan teknologi lainnya dalam industri 4.0 dan society 5.0, akan memberikan nilai tambah untuk layanan pendukung e-commerce sehingga semakin baik, canggih dan lebih komplek.

Kemitraan bisnis akan semakin terbuka lebar. Penggunaan internet akan membuka akses terhadap lintas batas antar negara, sehingga peluang untuk bermitra bisnis akan terbuka lebar tidak terbatas dalam satu negara saja tetapi bisa menggapai dunia internasional.

Teknologi e-commerce akan semakin baik, terbarukan dan lebih canggih. Karena e-commerce akan mengikuti dan menyesuaikan teknologinya dengan perkembangan teknologi pada era industri 4.0 dan society 5.0, pada era tersebut teknologi akan selalu berkembang sesuai dengan kebutuhan industri dan masyarakat.

\section{KESIMPULAN}

Era industri 4.0 dan society 5.0 merupakan era transformasi teknologi analog menjadi digital. Teknologi yang ada pada society 5.0 merupakan kelanjutan dari teknologi industri 4.0. Transformasi digital telah mengubah cara hidup masyarakat dan industri, sehingga membawa pengaruh yang besar terhadap kemajuan $e$-commerce. Keselarasan teknologi terjadi antara $e$-commerce dengan teknologi era industri 4.0 dan society 5.0, dimana teknologi e-commerce mengikuti dan menyesuaikan teknologinya dengan masing-masing era tersebut. Era industri 4.0 dan society 5.0 banyak memberikan dampak positif secara umum terhadap e-commerce, sehingga prospek pertumbuhan e-commerce akan semakin baik dimasa mendatang. 


\section{DAFTAR PUSTAKA}

Auliani, Palupi Annisa. 2019. AI, IoT, dan Tantangan Sektor Logistik di Era Revolusi Industri 4.0. Kompas.com, 11 Februari 2019. Diakses dari: https://ekonomi.kompas.com/read/2019/02/11/114445026/ai-iot-dantantangan-sektor-logistik-di-era-revolusi-industri-40?page=all, tanggal 22 Agustus 2019.

Auliani, Palupi Annisa. 2019a. Optimalisasi Perusahaan melalui Layanan "Shared Service" di Industri 4.0. Kompas.com, 23 Mei 2019. Diakses dari: https://money.kompas.com/read/2019/05/23/132110826/optimalisasiperusahaan-melalui-layanan-shared-service-di-industri-40?page=all, tanggal 28 Agustus 2019.

Bahrin, Mohd Aiman Kamarul et al. 2016. "Industry 4.0: A Review On Industrial Automation And Robotic", Jurnal Teknologi (Sciences \& Engineering) UTM 78 (6-13), 137-143. https://doi.org/10.11113/jt.v78.9285

Cabinet Office Japan Government. 2019. Society 5.0. Diakses dari: https://www8.cao.go.jp/cstp/english/society5_0/index.html, tanggal 6 Agustus 2019.

Fukuyama, Mayumi. 2018. "Society 5.0: Aiming for a New Human-Centered Society". Japan Economy Foundation Journal - Japan SPOTLIGHT. https://www.jef.or.jp/journal/pdf/220th_Special_Article_02.pdf. diakses tanggal 27 Agustus 2019.

Hendarsyah, Decky dan Retantyo Wardoyo. 2011. "Implementasi protokol diffiehellman dan algoritma RC4 untuk keamanan pesan SMS". IJCCS (Indonesian Journal of Computing and Cybernetics Systems) 5 (1), 14-25. https://doi.org/10.22146/ijccs.1997

Hendarsyah, Decky. 2012. "Keamanan Layanan Internet Banking Dalam Transaksi Perbankan”. IQTISHADUNA: Jurnal Ilmiah Ekonomi Kita 1 (1), 12-33.

Hendarsyah, Decky. 2015. "Bisnis Toko Online". IQTISHADUNA: Jurnal Ilmiah Ekonomi Kita 4 (1), 1-14.

Hendarsyah, Decky. 2016. "Penggunaan Uang Elektronik Dan Uang Virtual Sebagai Pengganti Uang Tunai Di Indonesia". IQTISHADUNA: Jurnal Ilmiah Ekonomi Kita 5 (1), 1-15.

Haryanti, Rosiana. 2019. "Society 5.0, Solusi Jepang Atasi Defisit Penduduk dan Infrastruktur". Kompas.com, 28 Januari 2019. Diakses dari: https://properti.kompas.com/read/2019/01/28/115422021/society-50solusi-jepang-atasi-defisit-penduduk-dan-infrastruktur?page=all, tanggal 6 Agustus 2019.

Kementerian Perindustrian. 2018. Making Indonesia 4.0: Strategi RI Masuki Revolusi Industri Ke-4. Diakses dari: https://kemenperin.go.id/artikel/18967/Making-Indonesia-4.0:-Strategi-RIMasuki-Revolusi-Industri-Ke-4, tanggal 30 Juli 2019.

Laudon, Kenneth C. and Carol Guercio Traver. 2014. E-Commerce: Business, Technology \& Society 10th edition. New Jersey: Pearson.

Nakanishi, Hiroaki and Hiroaki Kitano. 2018. "Society 5.0 Co-Creating The Future". Policy Proposals Industrial Technology, Keidanren (Japan Business

Federation). 
https://www.keidanren.or.jp/en/policy/2018/095.html. Diakses tanggal 23 Agustus 2019.

Pertiwi, Wahyunanda Kusuma. 2018. Jaringan 5G Pertama di Dunia Resmi Online. Kompas.com, 2 Oktober 2018. Diakses dari https://tekno.kompas.com/read/2018/10/02/16060047/jaringan-5gpertama-di-dunia-resmi-online, tanggal 29 Agustus 2019.

Rahayu, Ning. 2019. Pertumbuhan E-Commerce Pesat di Indonesia. Warta Ekonomi Online, 19 Februari 2019. Diakses dari: https://www.wartaekonomi.co.id/read216302/pertumbuhan-e-commercepesat-di-indonesia.html, tanggal 21 Agustus 2019.

Rahman, Adi Fida. 2019. Kapan Indonesia Bisa Nikmati 5G?. Detik.com, 1 Mei 2019. Diakses dari: https://inet.detik.com/telecommunication/d4532282/kapan-indonesia-bisa-nikmati-5g, tanggal 29 Agustus 2019.

Roby, Muhammad. 2019. Mengenal Rancangan Jepang Mengenai Society 5.0. 4 April 2019. Diakses dari: https://www.anakteknik.co.id/a/MhdRoby/Mengenal-Rancangan-Jepang-Mengenai-Society-50, tanggal 6 Agustus 2019.

Rojko, Andreja. 2017. "Industry 4.0 Concept: Background and Overview". International Journal of Interactive Mobile Technologies (iJIM) 11 (5), 77-90. https://doi.org/10.3991/ijim.v11i5.7072.

Savrul, Mesut and Cüneyt Kilıç. 2011. "E-Commerce As An Alternative Strategy In Recovery From The Recession". $7^{\text {th }}$ International Strategic Management Conference, Procedia Social and Behavioral Sciences 24, 247-259. Elsevier.

Turban, Efraim et al. 2015. Electronic Commerce: A Managerial and Social Networks Perspective Eighth Edition. Switzerland: Springer.

Wang, Cheng-Xiang et al. 2014. "Cellular Architecture and Key Technologies for 5G Wireless Communication Networks". IEEE Communications Magazine, Februari 2014.

$\mathrm{Xu}$, Li Da et al. 2018. "Industry 4.0: State Of The Art And Future Trends". International Journal of Production Research 56 (8), 2941-2962. https://doi.org/10.1080/00207543.2018.1444806

Zuraya, Nidia. 2019. Pertumbuhan E-Commerce Indonesia Tertinggi di Dunia. Republika Online, 27 Februari 2019. Diakses dari: https://www.republika.co.id/berita/ekonomi/korporasi/pnkrfg383/pertumb uhan-emecommerceem-indonesia-tertinggi-di-dunia, tanggal 21 Agustus 2019. 